MATEC Web of Conferences 25,03019 (2015)

DOI: $10.1051 /$ matecconf/ 20152503019

(C) Owned by the authors, published by EDP Sciences, 2015

\title{
Working Vibration Analysis of the Bearing Plate on Roadheader Test Bed
}

Yi Liu

Large-scale industrial and mining equipment detection and control key constructed laboratory of Jiangsu Province in Xu Zhou institute of Technology, Xuzhou, Jiangsu, China

Yang Gao

Liaoning University of Technology, Jinzhou, Liaoning, China

Yingying Zhang

Jinzhou Teachers Training College, Jinzhou, Liaoning, China

Jiaxing Fu

Coal Mining \& Designing Department, Tiandi Science \& Technology Co., Ltd, Beijing, China

Chuanhui Huang

Large-scale industrial and mining equipment detection and control key constructed laboratory of Jiangsu Province in Xu Zhou institute of Technology, Xuzhou, Jiangsu, China

\begin{abstract}
In order to research the vibration characteristics of the bearing plate on roadheader test bed to bear the roadheaders with different parameters, this paper establishes a multi-body dynamic model for the bearing plate to bear the roadheaders by using the theory of multi-body dynamics, and analyzes and determines a mathematical model of loads between the track and the bearing plate. By modal analysis of multi-body dynamic model of the roadheader, this paper extracts the modal shape of the system, and draws a frequency response diagram for system vibration, and obtains a larger vibration frequency range. To further explore the vibration characteristics, this paper researches the damping of different hydraulic systems, different mass, stiffness parameters and the impact of the roadheader on the vibration of the bearing plate on the test bed by using the computer numerical simulation, and obtains the longitudinal vibration characteristics of three test points in the geometric center, namely, cutting head, cantilever and engine body. The research results show that the mass of the roadheader on the test bed is increased by $6 \%$, and the longitudinal amplitudes of the cutting head and cantilever are respectively reduced by $37 \%$ and $19 \%$; the damping of the hydraulic system of the roadheader is increased by $19 \%$, and the longitudinal amplitudes of the cutting head, cantilever and engine body are respectively reduced by $33 \%, 23 \%$ and $16 \%$; the stiffness of the engine body doubles, and the longitudinal amplitudes of the cutting head and cantilever are respectively reduced by $35.8 \%$ and $27 \%$. The results are consistent with the underground industrial test so as to provide a regularity basis for load analysis of the test bed bearing the roadheaders with different parameters.
\end{abstract}

Keywords: roadheader test bed; plating board; cutting head; fake rock wall; modal analysis

\section{INTRODUCTION}

The roadheader vibration in operation is obvious due to poor working environment of the roadheader and the complex and varied loads, which directly affects the operational reliability of the mechanical parts, hydraulic components and electrical components as well as the operational stability of the complete machine, and reduces its work efficiency and service life of the roadheader. The research purpose of the heavy coal mine roadheader test bed is to improve the design of the roadheader and simulate real well mining environment to establish a testing system ${ }^{[1]}$. The whole experiment system of the heavy coal mine roadheader test bed is ultimately demonstrated as follows: The bearing plate which is directly connected with the track of the roadheader bears the roadheader and implements the headwork.

The longitudinal incentive between the track and the bearing plate is generated due to the impact of the load of the cutting head; what's more, its interaction with the load of the bearing plate causes the longitudinal vibration of the roadheader to be fiercer. Therefore, based on the actual working conditions of the vertical axis roadheader, this paper will adopts the theory of multi-body dynamics to research the longitudinal vibration characteristics of the roadheader through the computer modeling and simulation, so as to provide basis for improvement of design and development of the heavy coal mine roadheader test bed. 


\section{MATEC Web of Conferences}

2 WAY OF TEST BED BEARING ROADHEADER

The heavy coal mine roadheader test bed bears the roadheader to carry out the simulation experiment of working conditions. Taking the vertical axis roadheader as an example, the roadheader on the bearing plate of the test bed cuts fake rock wall on the front end of the test bed. Its application mode is shown in Figure 1:

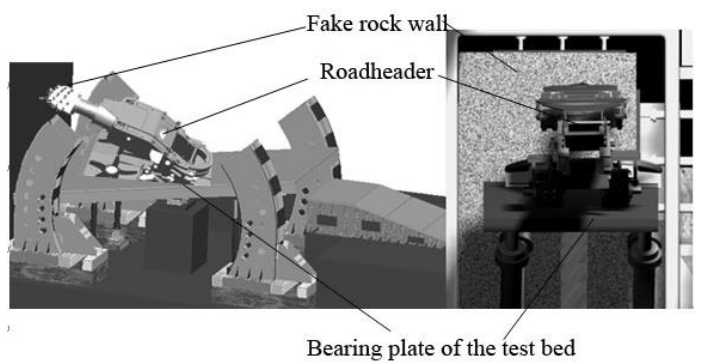

Figure 1. Cutting experiment system of the test bed roadheader

The bearing plate of the test bed is directly connected with the roadheader in the actual work. The vibration of the cutting head of the roadheader cutting rock wall, the vibration of the roadheader and other loads are eventually passed to the bearing plate of the test bed through the track of roadheader. However, the cutting work load and working conditions are uncertain, so it is impossible to carry out modeling calculation through a completely ideal statics model, and it is impossible to directly implement the analysis of mechanical characteristics of the bearing plate of the test bed. Therefore, there is a need to place on the bearing plate and cut the rock wall through research of the roadheader with different mass, damping, stiffness and other parameters, and vibration of key parts of the roadheader.

\section{DYNAMIC MODEL OF CONNECTION BE- TWEEN TRACK AND BEARING PLATE}

The roadheader is a construction-work-type track-laying vehicle at a low speed. The connection mode of the rigid track link only allows forming a convex surface related to the bearing plate rather than the concave surface; in addition, there is a certain plastic deformation between the track and the bearing plate ${ }^{[2]}$. Therefore, the dynamic model between the track and the bearing plate in the operation of the roadheader can be considered as a linear vibration system. This system is an unidirectional linear vibration system, of which the track mass is $m$, the stiffness coefficient between the track and the bearing plate is $k$, and the constant of damping coefficient between the track and the bearing plate is $c$ (see Figure 2). Its kinetic equation is:

$$
m \ddot{z}+c \dot{z}+k z=c \dot{q}+k q=f(t)
$$

Where: $q$-base longitudinal displacement; $f$ $(t)$-longitudinal excitation force; $z$-displacement; $z$ - speed; $z$-acceleration.

In the event of cutting by the roadheader, the track bears the tractive resistance of the bearing plate $\left(F_{Z}\right)$, lateral resistance $\left(F_{X}\right)$, shear stress $(\tau)$, supportiveness of the bearing plate $(N)$ and frictional force $\left(f_{z}\right.$ and $\left.f_{x}\right)$, which is shown in Figure 3.

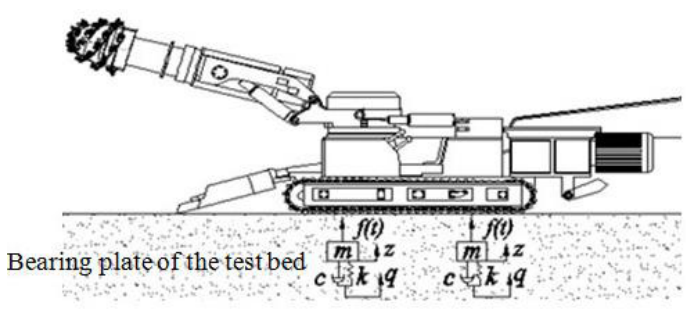

Figure 2. Linear vibration model of the track and the bearing plate

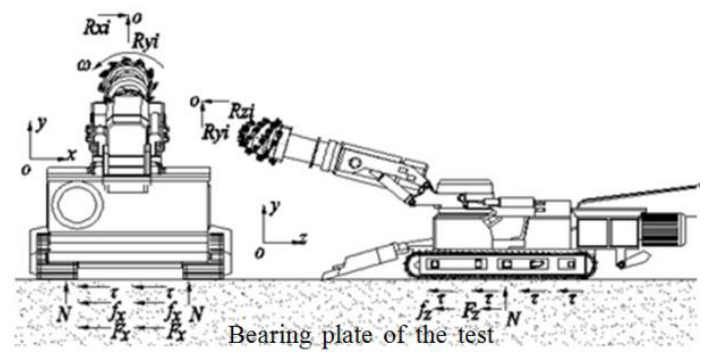

Figure 3. Load analysis of the track and the bearing plate

\section{RIGID MULTI-BODY DYNAMIC MODEL OF ROADHEADER ON THE BEARING PLATE}

\subsection{Definition of load}

Based on the analysis of the cutting head load and the load between the track and the bearing plate, and in ADAMS environment, we define the damping between the track and the bearing plate, the contact force and frictional force between components. They are shown in Figure 4, and their parameters are shown in Table 1. Because each component is in rigid connection, the contact force applied to each connection point, frictional force and damping parameters between components are shown in Table 2. By the use of $I F$ function, the three-dimensional force is individually applied to each cutting pick according to the position angle of cutting pick ${ }^{[3]}$, and its function expression is 


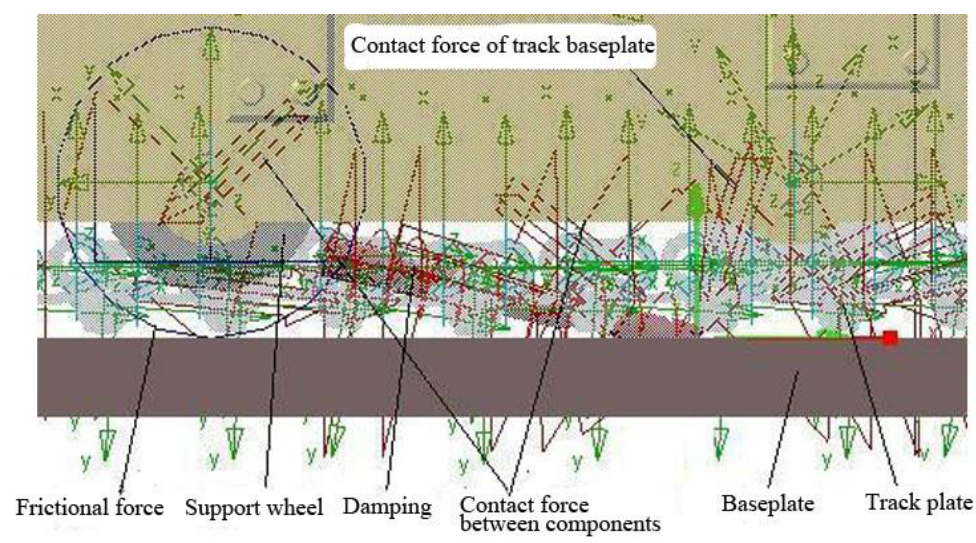

Figure 4. Contact load model of the track and the bearing plate

Table 1. Load parameters between the track and the bearing plate

\begin{tabular}{lllllll}
\hline Parameters & \multicolumn{2}{l}{$\begin{array}{l}\text { Resistance coefficient between the track } \\
\text { and the bearing plate } \delta_{\max }\end{array}$} & $\begin{array}{l}\text { Damping coefficient between the track } \\
\text { and the bearing plate } c_{\max }\end{array}$ & $\begin{array}{l}\text { Friction coeffi- } \\
\text { cient } \mu_{\max }\end{array}$ \\
\hline $\begin{array}{l}\text { Numerical } \\
\text { value }\end{array}$ & 0.678 & & 0.8411 & 0.973 \\
\hline \\
Table 2. Rigid body collision parameters
\end{tabular}

$I F\left(\sin \left(\Phi_{t}\right), 0,0, F\right)$. Where: $\Phi_{t}=\omega t+\beta, \Phi_{t}$-instantaneous position angle of cutting pick; $F$ - cutting pick load; $\omega$-cutting head speed; $\beta$-initial angle of cutting pick.

\subsection{Establishment of three-dimensional model}

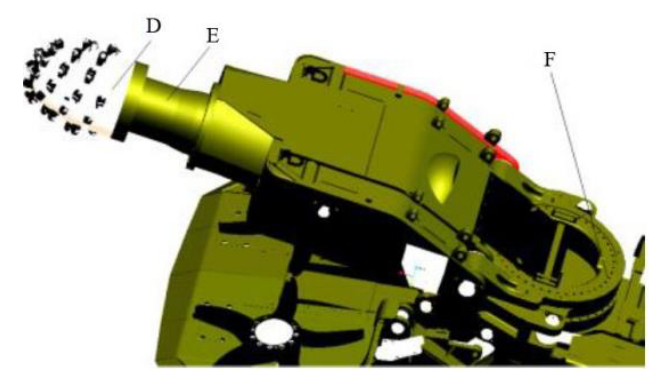

Figure 5. Rigid multi-body dynamic model of vertical axis roadheader

The three-dimensional model of roadheader established by the use of Pro/e is seamlessly connected with ADAMS through MechPro to define the rigid body and add constraint in Pro/e and map it to ADAMS to define the material attribution, mass, load and contact force, frictional force and damping parameters between components. The geometric center of the cutting head, cantilever and engine body is a connection point of the rigid members, so these three geometric coordinate centers (points D, E and F) are defined as the measuring points of the vibration simulation. The cutting head and fake rock wall are involved in the cut-in simulation experiment. The completed rigid multi-body dynamic model of the complete machine is shown in Figure 5.

\section{SIMULATION ANALYSIS}

The research object is a certain type of vertical axis roadheader, and its relevant parameters are as follows: The specification of the cutting head is $\Phi 980 \times 1,000 \mathrm{~mm} ; \quad$ stiffness $k_{l}=8 \times 105 \mathrm{~N} / \mathrm{m} ; \quad$ mass $m_{2}=1,050 \mathrm{~kg}$; number of revolutions $\omega=23 \mathrm{r} / \mathrm{min}$; number of cutting pick $n=48$; stiffness of the cantilever $k_{2}=$ $6.72 \times 10^{5} \mathrm{~N} / \mathrm{m}$; mass $m_{3}=2,420 \mathrm{~kg}$; stiffness of the engine body $k_{3}=3.86 \times 10^{3} \mathrm{~N} / \mathrm{m}$; mass $m_{4}=56,535 \mathrm{~kg}$. The damping coefficients of the hydraulic system of the feed cylinder, lift cylinder and angling cylinder are respectively as follows: $c_{I}=5.83 \times 10^{4} \mathrm{~N} \cdot \mathrm{s} / \mathrm{m}$; $c_{2}=3.75 \times 104 \mathrm{~N} \cdot \mathrm{s} / \mathrm{m} ; c_{3}=3.36 \times 104 \mathrm{~N} \cdot \mathrm{s} / \mathrm{m}$. 
MATEC Web of Conferences

\begin{tabular}{llll}
\hline \multicolumn{2}{l}{ Table 3. Modal data } \\
\hline Order & Natural frequency & Damping ratio & Working frequency \\
\hline 1 & 0 & $0.00000 \mathrm{E}+000$ & $0.00000 \mathrm{E}+000$ \\
2 & 0 & $0.00000 \mathrm{E}+000$ & $0.00000 \mathrm{E}+000$ \\
3 & 0 & $0.00000 \mathrm{E}+000$ & $0.00000 \mathrm{E}+000$ \\
4 & $1.307803 \mathrm{E}+000$ & $1.00000 \mathrm{E}+000$ & $0.00000 \mathrm{E}+000$ \\
5 & $1.577163 \mathrm{E}+001$ & $1.00000 \mathrm{E}+000$ & $0.00000 \mathrm{E}+000$ \\
6 & $2.718770 \mathrm{E}+000$ & $7.444259 \mathrm{E}-001$ & $+/-2.718000 \mathrm{E}+000$ \\
7 & $2.118770 \mathrm{E}+002$ & $2.203758 \mathrm{E}-001$ & $+/-2.118000 \mathrm{E}+001$ \\
\hline
\end{tabular}

\subsection{Modal analysis}

Adams/virbution experimental modal analysis can be used to analyze the vibration characteristics of the cutting head, cantilever and engine body. The modal data of extracting order 7 are shown in Table 3; the two-dimensional frequency response of longitudinal displacement is shown in Figure 6:

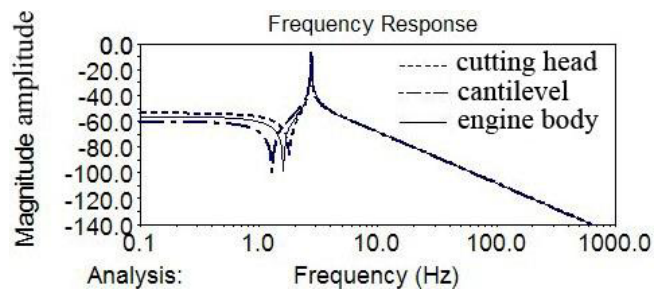

Figure 6. Frequency response of longitudinal acceleration

As can be seen from Figure 6, the inherent frequency of the modal in the former three orders is zero without resonance phenomenon; vibration of the complete machine is not obvious. The peak value of the longitudinal frequency response of the cutting head, cantilever and engine body is respectively at about $1.3 \mathrm{~Hz}, 1.6 \mathrm{~Hz}$ and $2 \mathrm{~Hz}$, which is close to the inherent frequency in the fourth order, so that the vibration increases. Three test points have a peak value at a frequency of $2.8 \mathrm{~Hz}$, which is close to the modal in the sixth order, with its inherent frequency of $2.71770 \mathrm{~Hz}$ and damping ratio of $7.444259 \mathrm{E}-001$. It is the vibration inherent frequency of the whole machine (namely, engine body, cantilever and cutting head) system under the combined action of the cutting head load and the bearing plate load, and its main mode of vibration is as follows: If the vibration amplitude of engine body is large, the longitudinal vibration amplitude of the complete machine is also large. As can be seen from the frequency response diagram, the vibration peak values are mainly concentrated in the range of $1.0-3.0 \mathrm{~Hz}$; the curves at other frequency bands are relatively flat without large vibration. Therefore, the vibration can be reduced by changing the mass, stiffness of the system, damping and other parameters of the hydraulic system ${ }^{[4]}$.

\subsection{Longitudinal vibration analysis}

When the cutting head cuts fake rock wall, , the simulation analysis can be carried out for longitudinal (Y-axis direction) vibration of three test points under different mass, stiffness and damping of the hydraulic system in the process of transverse cutting by the roadheader ${ }^{[7,8]}$, according to the rigid multi-body dynamic model of the roadheader ${ }^{[5,6]}$. And according to the simulation of initial parameters, the vibration curves of the cutting head, cantilever and engine body can be obtained as shown in Figure 7. The amplitudes of test points $\mathrm{D}, \mathrm{E}$ and $\mathrm{F}$ are respectively $28 \mathrm{~mm}$, $11 \mathrm{~mm}$ and $6 \mathrm{~mm}$.

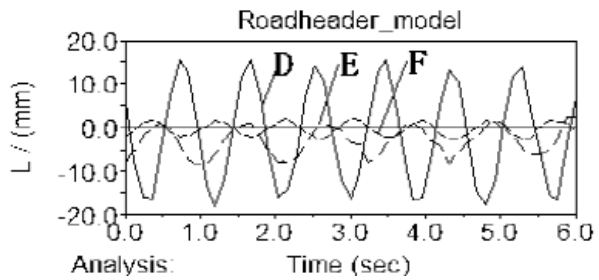

Figure 7. Simulation results of initial conditions

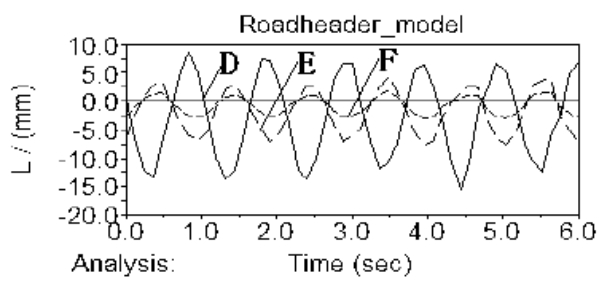

Figure 8. Simulation results of damping changes

\subsubsection{Impact of damping in the hydraulic system}

When the cutting head cuts the fake rock wall, the damping of the hydraulic system of the feed cylinder, 
lift cylinder and angling cylinder is increased by $19 \%$, and the vibration curves of the cutting head, cantilever and engine body are shown in Figure 8. Compared with Figure 7, the vibration amplitudes of the cutting head, cantilever and engine body are respectively reduced by $33 \%, 23 \%$ and $16 \%$. Thus the change of damping of the hydraulic system has a great impact on the vibration of the cutting had but a small impact on the vibration of the engine body.

\subsubsection{Impact of mass in each component}

When the cutting head cuts the fake rock wall, the mass of the cutting head, cantilever and engine body are respectively increased by $19 \%, 19 \%$ and $6 \%$, and the simulation results of vibration of each component are respectively shown in Figure 9 (a), Figure 9 (b) and Figure 9(c). Compared with Figure 7, the amplitudes of points $\mathrm{D}, \mathrm{E}$ and $\mathrm{F}$ under three conditions are respectively reduced by $27 \%, 31 \%$ and $48 \%$. As can be seen from the Figure 9 (a) and Figure 9 (b), the increase of the mass of the cutting head and cantilever can effectively reduce the vibration of the cutting head, but the mass of the engine body is increased by $6 \%$, and the amplitudes of the cutting head and cantilever are respectively reduced by $37 \%$ and $19 \%$, and the vibration amplitude of the engine body is also reduced significantly (see Figure 9 (c)).

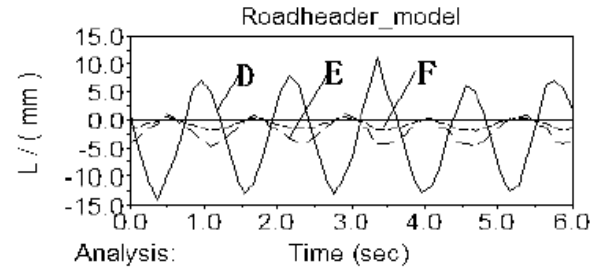

(a)

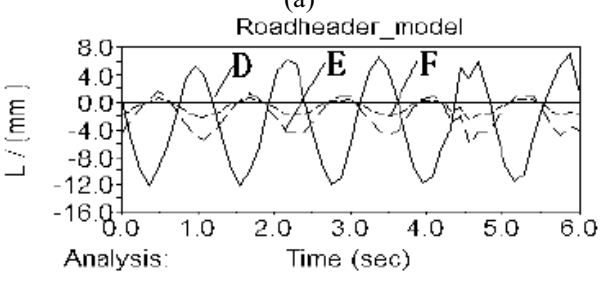

(b)

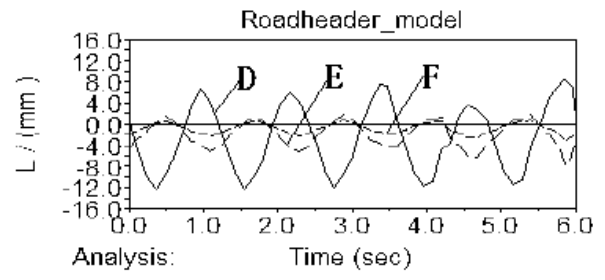

(c)

Figure 9. Simulation results of mass changes

5.2.3 Impact of stiffness in each component Figure 10 (a), Figure 10 (b) and Figure 10 (c) are re- spectively the simulation results that the stiffness value of the cutting head, cantilever and engine body respectively doubles the original value. Thus stiffness changes have great impacts on the vibration of roadheader. With respect to Figure 7, the increase of the stiffness of the cutting head and cantilever (see Figure 10 (a) and Figure 10 (b)) makes the vibration of the cutting head be respectively reduced by $36 \%$ and $36.7 \%$; the increase of the stiffness of engine body has a greatest impact on the vibration of the roadheader, which makes the amplitudes of points $\mathrm{D}, \mathrm{E}$ and $\mathrm{F}$ be respectively reduced by $35.8 \%, 27 \%$ and $40 \%$ (see Figure 10 (c)).

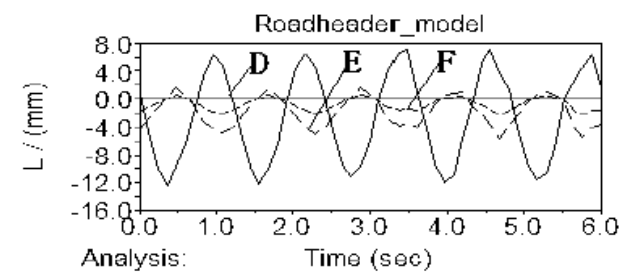

(a)

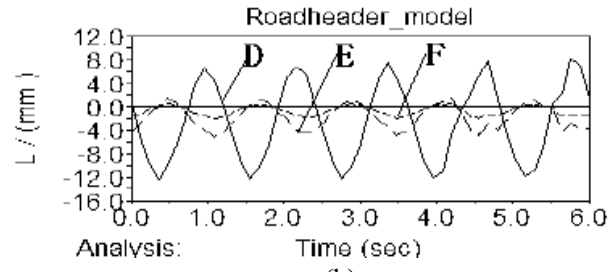
(b)

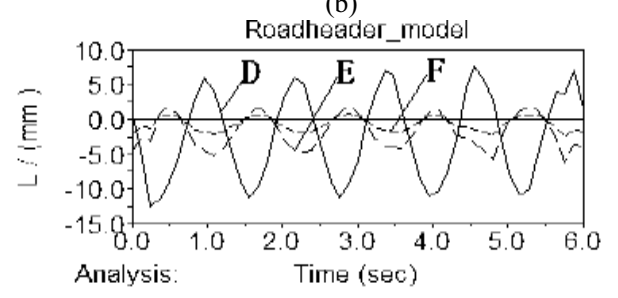

(c)

Figure 10. Simulation results of stiffness changes

\section{CONCLUSION}

(1) When we extract the test roadheader, place it on the bearing plate of the test bed, and cut the fake rock wall, we study the modal vibration characteristics of the cutting head, cantilever and engine body and then find that the frequency range of larger vibration is concentrated in $1-3 \mathrm{~Hz}$. This conclusion lays a foundation for further analysis of the incentives of the roadheader to the bearing plate of test bed.

(2) The greater the damping of the hydraulic system of the roadheader on the bearing plate is, the smaller the vibration to some extent is that is, the smaller the vibration incentive of the bearing plate is.

(3) The greater the impact of the mass and stiffness of the cutting head on the vibration of the roadheader is, the greater the coupling stiffness between the cut- 


\section{MATEC Web of Conferences}

ting head and the cantilever of the roadheader is, and the smaller the vibration load of the bearing plate is.

(4) The greater the impact of the mass of the engine body on its vibration is, the greater the mass of the test roadheader is, and the smaller the vibration incentive of the bearing plate is.

\section{REFERENCES}

[1] Fu Jiaxing. 2012. Research of project design and key technology of heavy coal mine roadheader test bed. Fuxin: Master's Thesis of Liaoning Project Technology University.

[2] Pan Xianfeng. 2011. Research of cutting performance for the EBZ-225 roadheader's cutting head. Hefei: Anhui University of Science and Technology, 58-65.

[3] Wang Dan. 2009. Mechanical property and parameter optimization for cutting mechanism of vertical axis hard rock roadheader. Fuxin: Liaoning Project Technology University, 3-16.

[4] Dai Shanshan. 2012. Simulation of brittle coal cutting by conical pick based on ABAQUS. Coal Mine Machinery, 33 (5): 46-48.

[5] Zhou You. 2011. Improved design and dynamic simulation analysis of EBZ45 roadheader's cutting head. Changsha: Central South University, 40-53.

[6] Ye Mao, Tan Ping, \& Ren Min, et al. 2010. Random vibration analysis of bridge evolution under the effect of multiple vehicle loads. Journal of Vibration Engineering, 23 (3): 269-274.

[7] Li Xiaohuo, Liu Xia, \& Jiao Li, et al. 2010. Dynamic simulation of sliding coal plow under different working conditions. Journal of China Coal Society, 35 (7): 1202-1206.

[8] Zhang Jianguang. 2012. Experimental research of vibration characteristics of a vertical axis roadheader. Coal Mine Machinery, 18 (1): 24-26. 